\title{
Thin basement membrane syndrome in adults
}

\author{
S ABE, Y AMAGASAKI,* S IYORI, $\dagger$ K KONISHI, E KATO, H SAKAGUCHI, \\ K SHIMOYAMA** \\ From the Department of Internal Medicine and $\ddagger$ Pathology, Keio University School of Medicine, Tokyo, \\ the Department of *Internal Medicine and ${ }^{* *}$ Pathology, Saiseikai Yokohama City Nanbu Hospital, Yokohama, \\ and the $†$ Department of Internal Medicine, Hiratsuka City Hospital, Hiratsuka, Japan
}

SUMMARY Eight (two men, six women) cases of adult thin basement membrane syndrome were studied to clarify the clinicopathological characteristics of the disease. The average age at the time of biopsy was 40 years. All the patients had persistent microscopic haematuria, normal renal function, and normal blood pressure, with the exception of one who was hypotensive. Most of them had persistent or transient proteinuria. Renal symptoms were found in four families, although no relative had Alport's syndrome. Renal biopsy findings observed by light and immunofluorescence microscopy did not indicate any important abnormalities, but extensive diffuse thinning of the glomerular basement membrane, ranging from 153 to $213 \mathrm{~nm}$, was a constant finding by electron microscopy. All the patients retained stable renal function at the time of final follow up, indicating a benign prognosis of the syndrome.

It is widely known that diffuse thinning of the glomerular basement membrane can be seen in the early stages of Alport's syndrome ${ }^{1}$ or in cases of benign recurrent haematuria in children ${ }^{2-4}$ : segmental thinning of glomerular basement membrane is often found in various glomerular diseases such as $\operatorname{IgA}$ nephropathy ${ }^{5}$ or membranoproliferative glomerulonephritis. ${ }^{1}$ The incidence of isolated, diffuse, thin glomerular basement membrane nephropathy, or thin basement membrane syndrome in adults, however, is thought to be rare, and published reports are scarce. ${ }^{6}$

We collected eight cases of adult thin basement membrane syndrome from among 998 patients whose renal biopsy specimens were observed by electron microscopy. The aim of this paper was to focus on the clinicopathological characteristics of the disease that we observed and to state differences between these findings and those of previously published reports.

\section{Material and methods}

Thin basement membrane syndrome is defined in this paper as follows: (i) minor abnormalities seen in glomeruli by light microscopy-that is, which are apparently normal or show only minor changes by light microscopy ${ }^{1}$; (ii) diffuse thinning of glomerular basement membrane, to $\leqslant 200 \mathrm{~nm}$; (iii) deposits of immunoglobulins and complement components that are not detectable by immunofluorescence microscopy; (iv) exclusion of Alport's syndrome or systemic diseases that accompany renal disease.

Of the adult renal biopsy specimens examined by light, electron, and immunofluorescence microscopy at the department of pathology of Keio University between 1964 and 1983, eight cases met the above criteria; these were referred to Keio University Hospital, or its affiliated hospitals, for diagnostic evaluation of asymptomatic haematuria or proteinuria, or both, and were followed up with renal checkups, including renal biopsy.

Electron micrographs of all cases were carefully studied by one of us (HS) and 35, with only diffuse thinning of glomerular basement membrane, were selected. The thickness of glomerular basement membrane in these cases was then measured according to the method reported by Osawa et al. ${ }^{8}$ The measurements were done only in the peripheral portions of the capillaries where the epithelial and endothelial cytoplasmic membranes were clearly visible. The distance between the epithelial and endothelial cytoplasmic membranes was measured as the thickness of glomerular basement membrane. About 100 measurements per case were taken at intervals of $1 \mu \mathrm{m}$. 
Results

Of 998 cases, eight satisfied the criteria of thin basement membrane syndrome, placing the incidence of the disease at $0.8 \%$. Table 1 gives the relevant details about the patients.

Urinary abnormalities were discovered incidentally by physical checkups in four patients; the remainder were found during the investigation of such symptoms as urinary tract infection, the common cold, or abdominal pain. These urinary abnormalities were found in patients aged between 18 and 50 years, median 33 years.

Four families had had one or more cases of renal disease or haematuria, although a precise renal work up, including biopsy, could not be performed. None of them progressed to end stage renal failure, or had neurosensory deafness, or ocular abnormalities.

Table 2 summarises the main clinical data collected at the time of biopsy. Repeated urinalysis showed that five patients had a mild degree of proteinuria, ranging between $(+)$ and $(++)$; in case 6 , however, it was always negative, while in cases 5 and $8,(-)$ or $( \pm)$ degree of protein was found. All these patients had persistent microscopic haematuria; but macroscopic haematuria, especially that exacerbated by upper respiratory tract infection, was not observed. Granular or cellular casts were found in only two cases.

Serum urea, nitrogen, creatinine concentrations and creatinine clearance were all within normal limits. Abnormalities were not observed in immunoglobulins and complement components. Intravenous pyelography showed normal findings, and urological disorders were ruled out.

Table 3 details the renal biopsy findings. Light microscopy showed that the glomeruli seemed to be nearly normal and were therefore judged to be showing only minor abnormalities according to World Health Organisation's definition of glomerular diseases (fig 1). Obvious tubulointerstitial changes and arteriolosclerosis were not found.

Electron microscopic observation indicated extensive diffuse thinning of glomerular basement mem-

Table 1 Clinical data of patients with thin basement membrane syndrome

\begin{tabular}{|c|c|c|c|c|c|c|c|}
\hline $\begin{array}{l}\text { Case } \\
\text { no }\end{array}$ & Sex & $\begin{array}{l}\text { Age at } \\
\text { renal } \\
\text { biopsy } \\
\text { (years) }\end{array}$ & History* & $\begin{array}{l}\text { Reason for discovery } \\
\text { of urinary } \\
\text { abnormality }\end{array}$ & $\begin{array}{l}\text { Age at discovery } \\
\text { of urinary } \\
\text { abnormality (years) }\end{array}$ & Family history & $\begin{array}{l}\text { No of family } \\
\text { members whose } \\
\text { urine was tested }\end{array}$ \\
\hline 1 & $\mathbf{F}$ & 41 & & Physical checkup & 32 & & 3 \\
\hline 2 & $\mathbf{M}$ & 35 & Purpura aged 10 & Physical checkup & 18 & $\begin{array}{l}\text { Three daughters, } \\
\text { transient } \\
\text { haematuria }\end{array}$ & 7 \\
\hline 3 & $\mathbf{F}$ & 43 & $\begin{array}{l}\text { Acute } \\
\text { glomerulonephritis } \\
\text { aged } 22\end{array}$ & $\begin{array}{l}\text { Symptoms of urinary } \\
\text { tract infection }\end{array}$ & 33 & $\begin{array}{l}\text { One child, } \\
\text { haematuria }\end{array}$ & 4 \\
\hline 4 & $\mathbf{M}$ & 32 & & $\begin{array}{l}\text { Symptoms of common } \\
\text { cold }\end{array}$ & 30 & $\begin{array}{l}\text { Mother, renal } \\
\text { disease }\end{array}$ & 4 \\
\hline 5 & $\mathbf{F}$ & 35 & $\begin{array}{l}\text { Rheumatic fever } \\
\text { aged } 10\end{array}$ & Physical checkup & 19 & $\begin{array}{l}\text { Father and two } \\
\text { brothers, } \\
\text { haematuria }\end{array}$ & 6 \\
\hline 6 & $\mathbf{F}$ & 47 & & $\begin{array}{l}\text { Symptoms of urinary } \\
\text { tract infection }\end{array}$ & 42 & & 6 \\
\hline $\begin{array}{l}7 \\
8\end{array}$ & $\begin{array}{l}\mathbf{F} \\
\mathbf{F}\end{array}$ & $\begin{array}{l}39 \\
50\end{array}$ & & $\begin{array}{l}\text { Physical checkup } \\
\text { Symptoms of abdominal } \\
\text { pain }\end{array}$ & $\begin{array}{l}39 \\
50\end{array}$ & & $\begin{array}{l}5 \\
4\end{array}$ \\
\hline
\end{tabular}

*negative except where stated.

Table 2 Clinical data at time of renal biopsy

\begin{tabular}{|c|c|c|c|c|c|c|c|c|c|c|}
\hline \multirow[b]{2}{*}{$\begin{array}{l}\text { Case } \\
\text { no }\end{array}$} & \multirow{2}{*}{$\begin{array}{l}\text { Blood } \\
\text { pressure } \\
(\mathrm{mm} \mathrm{Hg})\end{array}$} & \multirow[b]{2}{*}{ Proteinuria } & \multicolumn{3}{|c|}{ Urinary sediment } & \multirow{2}{*}{$\begin{array}{l}\text { Urea } \\
\text { nitrogen } \\
(m g / d l)\end{array}$} & \multirow[b]{2}{*}{$\begin{array}{l}\text { Creatinine } \\
(m g / d l)\end{array}$} & \multirow{2}{*}{$\begin{array}{l}\text { Glomerular } \\
\text { filtration } \\
\text { rate } \\
(\mathrm{ml} / \mathrm{min})\end{array}$} & \multirow[b]{2}{*}{$\begin{array}{l}\text { Intravenous } \\
\text { pyelography }\end{array}$} & \multirow[b]{2}{*}{$\begin{array}{l}\text { Hearing } \\
\text { loss }\end{array}$} \\
\hline & & & $\begin{array}{l}\text { Red } \\
\text { blood cells }\end{array}$ & $\begin{array}{l}\text { White } \\
\text { blood cells }\end{array}$ & Casts & & & & & \\
\hline $\begin{array}{l}1 \\
2 \\
3 \\
4 \\
5 \\
6 \\
7 \\
8\end{array}$ & $\begin{array}{r}122 / 78 \\
108 / 74 \\
120 / 80 \\
112 / 84 \\
110 / 60 \\
90 / 40 \\
126 / 86 \\
128 / 76\end{array}$ & $\begin{array}{l}( \pm)-(++) \\
(+)-(++) \\
(+)-(++) \\
(+)-(++) \\
(-)-( \pm) \\
(-) \\
(+)-(++) \\
(-)-( \pm)\end{array}$ & $\begin{array}{r}3-8 \\
10-15 \\
80-90 \\
25-30 \\
>100 \\
15-30 \\
60-80 \\
10-20\end{array}$ & $\begin{array}{l}1-2 \\
2-3 \\
1-2 \\
2-3 \\
2-3 \\
(-) \\
2-3 \\
2-3\end{array}$ & $\begin{array}{l}(-) \\
(-) \\
(+) \\
(-) \\
(-) \\
(-) \\
(+) \\
(-)\end{array}$ & $\begin{array}{l}11 \cdot 7 \\
15 \cdot 4 \\
17 \cdot 1 \\
14 \cdot 0 \\
14 \cdot 0 \\
18 \cdot 0 \\
14 \cdot 0 \\
15 \cdot 3\end{array}$ & $\begin{array}{l}1.1 \\
0.9 \\
1.0 \\
1.0 \\
0.6 \\
0.6 \\
0.9 \\
1.2\end{array}$ & $\begin{array}{r}97 \\
112 \\
118 \\
116 \\
86 \\
103 \\
86 \\
82\end{array}$ & $\begin{array}{l}\text { Normal } \\
\text { Normal } \\
\text { Normal } \\
\text { Normal } \\
\text { Normal } \\
\text { Normal } \\
\text { Normal } \\
\text { Normal }\end{array}$ & $\begin{array}{l}(-) \\
(-) \\
(-) \\
(-) \\
(-) \\
(-) \\
(-) \\
(-)\end{array}$ \\
\hline
\end{tabular}




\begin{tabular}{|c|c|c|c|c|c|c|c|c|c|c|c|c|c|}
\hline \multirow[b]{2}{*}{$\begin{array}{l}\text { Case } \\
\text { no }\end{array}$} & \multicolumn{3}{|c|}{ Light microscopy findings } & \multicolumn{4}{|c|}{ Electron microscopy findings } & \multicolumn{6}{|c|}{ Immunofluorescence } \\
\hline & $\begin{array}{l}\text { Glomerular } \\
\text { changes }\end{array}$ & $\begin{array}{l}\text { Tubulo- } \\
\text { interstitial } \\
\text { changes }\end{array}$ & $\begin{array}{l}\text { Arteriolo- } \\
\text { sclerosis }\end{array}$ & $\begin{array}{l}\text { Thickness of } \\
\text { glomerular } \\
\text { basement } \\
\text { membrane } \\
\text { (nm) } \\
\text { Mean (SD) }\end{array}$ & $\begin{array}{l}\text { Additional } \\
\text { findings of } \\
\text { glomerular } \\
\text { basement } \\
\text { membrane }\end{array}$ & Deposits & $\begin{array}{l}\text { Effacement } \\
\text { of foot } \\
\text { processes }\end{array}$ & $\operatorname{Ig} G$ & $\operatorname{Ig} A$ & $\lg M$ & $C_{l q}$ & $C_{3}$ & Fibring \\
\hline $\left.\begin{array}{l}1 \\
2 \\
3 \\
4 \\
5 \\
6 \\
7 \\
8\end{array}\right\}$ & $\begin{array}{l}\text { Minor } \\
\text { abnormalities }\end{array}$ & $\begin{array}{l}(-) \\
10 \% \\
(-) \\
<5 \% \\
(-) \\
<5 \% \\
(-) \\
(-)\end{array}$ & $\begin{array}{l}(-) \\
(-) \\
(-) \\
(-) \\
(-) \\
(-) \\
(-) \\
(-)\end{array}$ & $\begin{array}{l}208(23) \\
153(23) \\
180(42) \\
175(35) \\
193(45) \\
198(37) \\
178(41) \\
213(35)\end{array}$ & $\begin{array}{l}(-) \\
\text { Wrinkling } \\
(-) \\
(-) \\
\text { Wrinkling } \\
\text { Wrinkling } \\
(-) \\
\text { Wrinkling }\end{array}$ & $\begin{array}{l}(-) \\
(-) \\
(-) \\
(-) \\
(-) \\
(-) \\
(-) \\
(-)\end{array}$ & $\begin{array}{l}(-) \\
(-) \\
( \pm) \\
(-) \\
(+) \\
( \pm) \\
(-) \\
(-)\end{array}$ & $\begin{array}{l}(-) \\
(-) \\
(-) \\
(\text { No } \\
(\text { No } \\
(-) \\
(-) \\
(-)\end{array}$ & $\begin{array}{l}(-) \\
(-) \\
(-) \\
\text { glomeru } \\
\text { glomeru } \\
(-) \\
(-) \\
(-)\end{array}$ & $\begin{array}{l}(-) \\
(-) \\
(-) \\
\text { ali) } \\
\text { ali) } \\
(-) \\
(-) \\
(-)\end{array}$ & $\begin{array}{l}(-) \\
(-) \\
(-)\end{array}$ & $\begin{array}{l}(-) \\
(-) \\
(-)\end{array}$ & $\begin{array}{l}(-) \\
(-) \\
(-)\end{array}$ \\
\hline
\end{tabular}

Per cent of tubulointerstitial changes indicates the percentage of cortical area with such changes.

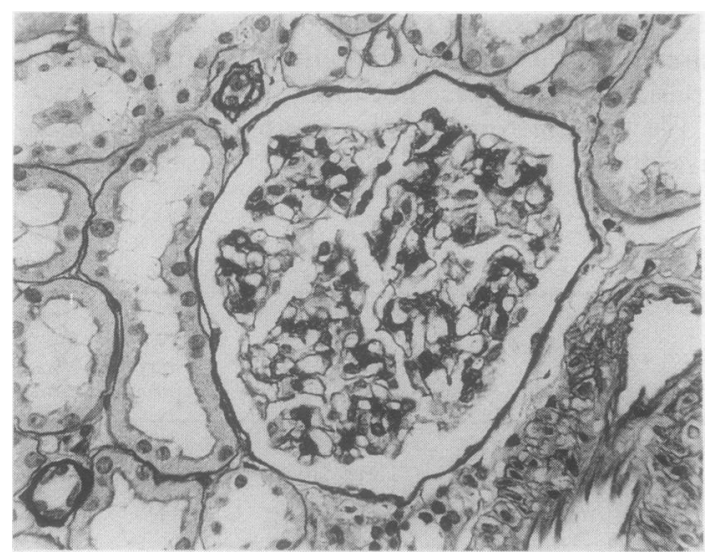

Fig 1 Light microscopy of thin basement membrane syndrome (case 6) showing minor abnormalities. (PAS stain). $\times 400$.

brane (fig 2). The thinning was caused by a decreased width of the lamina densa. The average thickness of glomerular basement membrane was between 153 and $213 \mathrm{~nm}$. No important difference was found between the intercapillary or intracapillary thickness of glomerular basement membrane. A mild degree of partial wrinkling of glomerular basement membrane was observed in four cases. Lamination, segmental thickening, and splitting of glomerular basement membrane were not found, nor were any deposits. Partial effacement of foot processes were seen in cases 3,5 , and 6 .

Results from immunofluorescence microscopy were negative for IgG, IgA, IgM, $C_{1 q}, C_{3}$ and fibrinogen in the glomeruli of six cases. In cases 4 and 5 , the glomeruli were not contained in the frozen material for the immunofluorescence technique.

At follow up (between two and 10 years, average 4.4 years after renal biopsy was performed) all these patients had retained stable renal function. Table 4 shows that the microscopic haematuria persisted at the time of final follow up.

\section{Discussion}

The nephropathy defined as "thin basement membrane syndrome" by the World Health Organisation's classification of glomerular diseases ${ }^{1}$ has been described as "thin membrane nephropathy", "thin glomerular basement membrane", 4 "thinning of the glomerular basement membrane", "glomerular basement membrane attenuation", ${ }^{2}$ or "extensive attenuation of the basement membrane". ${ }^{10}$ As there are no uniform criteria the cases with hardly any subnormal thickness of glomerular basement membrane or those with diffuse thinning accompanied by partial thickening, splitting, or lamination of glomerular basement membrane and deposits were sometimes included in previous reports. This might be due to the difference in approaching the syndrome-some took a clinical approach from the viewpoint of investigating idiopathic or familial haematuria, while others chose a pathological method based on a review of all renal biopsy cases, irrespective of clinical symptoms. To study the clinicopathological characteristics of the disease, we therefore applied rather strict criteria to exclude the borderline cases.

The incidence of the disease was considered to be rare among adults and more common in children. According to the findings of a recent paper, ${ }^{7}$ however, it is comparatively common in adults. We excluded seven cases from the study because of the presence of partial thickening, lamination of glomerular basement membrane, or dense deposits. Some of these cases could, in fact, be the syndrome accompanied by some other renal diseases. Bearing this in mind, the incidence might be higher than $0.8 \%$. The rate would become higher, for example, if renal biopsy specimens 


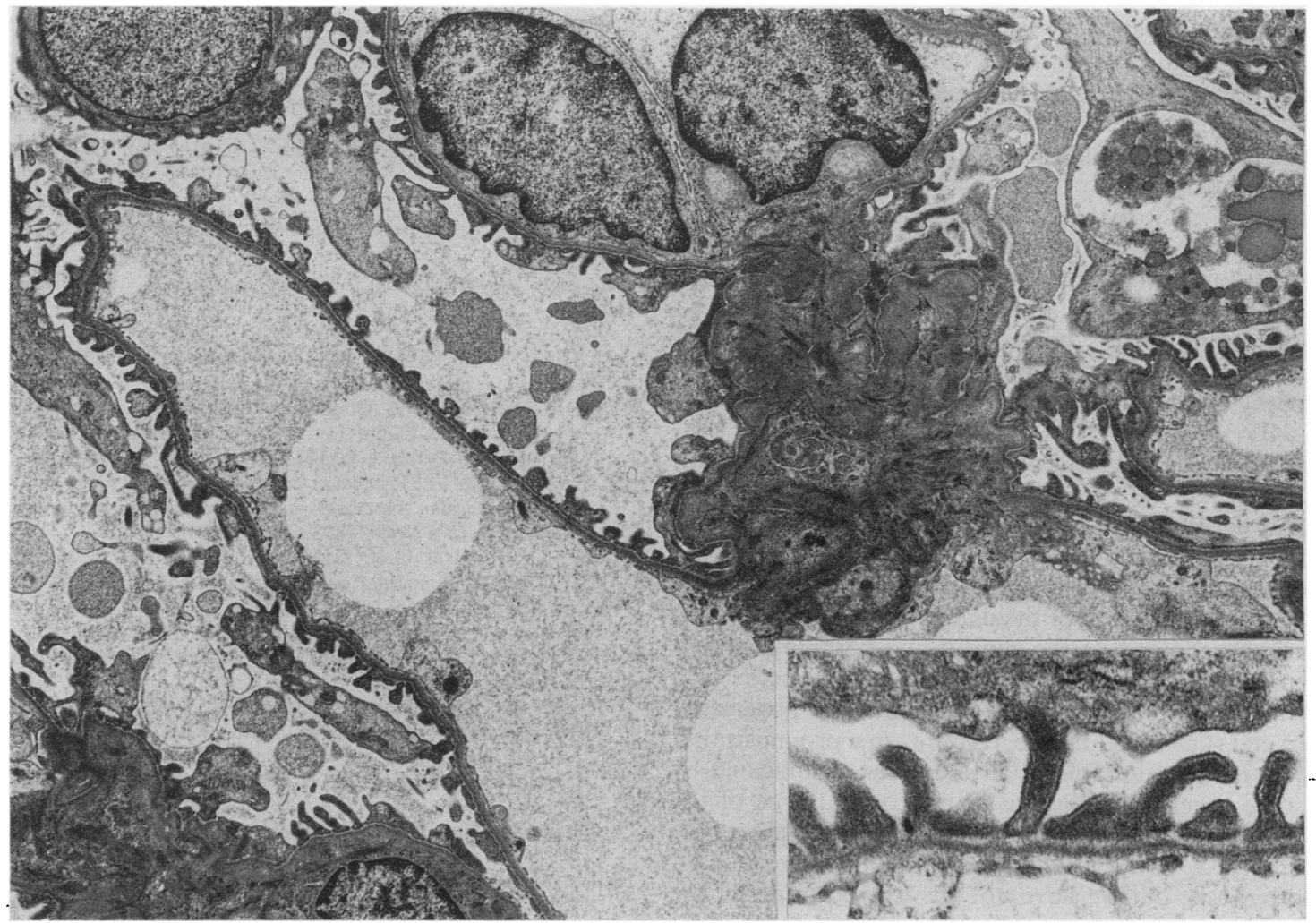

Fig 2 Electron micrograph of thin basement membrane syndrome (same case as that in Fig 1) showing extensively diffuse thinning of glomerular basement membrane. $\times 5000$. (Inset: higher magnification of glomerular basement membrane. $\times 22000$.)

Table 4 Clinical data at final follow up

\begin{tabular}{|c|c|c|c|c|c|c|}
\hline Case no & $\begin{array}{l}\text { Follow up after } \\
\text { renal biopsy } \\
\text { (years) }\end{array}$ & $\begin{array}{l}\text { Blood pressure } \\
\text { ( } \mathrm{mm} \mathrm{Hg})\end{array}$ & Proteinuria & $\begin{array}{l}\text { Red blood cells in } \\
\text { urinary } \\
\text { sediment }\end{array}$ & $\begin{array}{l}\text { Creatinine } \\
(\mathrm{mg} / d \mathrm{l})\end{array}$ & $\begin{array}{l}\text { Glomerular } \\
\text { filtration rate } \\
(\mathrm{ml} / \mathrm{min})\end{array}$ \\
\hline $\begin{array}{l}1 \\
2 \\
3 \\
4 \\
5 \\
6 \\
7 \\
8\end{array}$ & $\begin{array}{r}10 \\
6 \\
4 \\
2 \\
2 \\
3 \\
3 \\
2 \\
6\end{array}$ & $\begin{array}{r}122 / 78 \\
108 / 74 \\
120 / 80 \\
136 / 90 \\
110 / 60 \\
90 / 40 \\
118 / 80 \\
126 / 80\end{array}$ & $\begin{array}{l}( \pm) \\
(+++) \\
( \pm) \\
(+) \\
(-) \\
(-) \\
(++) \\
(-)\end{array}$ & $\begin{array}{l}10-12 \\
20 \\
>100 \\
80-100 \\
>100 \\
18-20 \\
30-40 \\
20-30\end{array}$ & $\begin{array}{l}0.8 \\
1.0 \\
1.0 \\
1.0 \\
0.6 \\
0.6 \\
1.0 \\
0.7\end{array}$ & $\begin{array}{r}102 \\
98 \\
107 \\
136 \\
103 \\
102 \\
89 \\
95\end{array}$ \\
\hline
\end{tabular}

are observed by electron microscopy in all the cases with chance haematuria.

Four families had one or more cases of renal symptoms, although none of them was diagnosed as having Alport's syndrome. Some reports have stated that thin glomerular basement membrane can be seen as one of the characteristics of familial haematuria, ${ }^{3}$ while others have reported that this condition was also found in patients whose relatives did not have renal diseases. ${ }^{4}$ It could be that the patients with no familial disease represented sporadic cases of familial haematuria. What remains to be solved is whether the condition is related to hereditary, environmental, nutritional or other factors. Purpura, acute glomerulonephritis, and rheumatic fever were listed in three patients, but these were diagnosed at least 21 years 
before renal biopsy was done and they had been completely cured. Furthermore, none of these conditions has been reported to be associated with thin glomerular basement membrane.

Clinically, all of these patients had microscopic haematuria, most of them had a mild degree of proteinuria and some had cylinduria. They were all asymptomatic with normal blood pressure, normal renal function, and normal serum immunoglobulins. From the above data, it was impossible to differentiate the syndrome from the latent type of chronic nephritic syndrome, including IgA nephropathy, without renal biopsy findings.

By the end of final follow up microscopic haematuria persisted but proteinuria had disappeared in two cases. No patient had become hypertensive or had developed impaired renal function. The disease seems to have a benign prognosis, considering that these patients were followed up for 11 years on average. A comparison of the data with those of previous reports shows that the clinical and pathological features were almost the same, but there were occasional cases with hypertension or those that had progressed to end stage renal failure, resulting in a prognosis that was not always benign. ${ }^{7}$ If the cases complicated by some other renal disease or an atypical type of the syndrome could be excluded and only a pure type observed, however, the syndrome may have a good prognosis, but we have not yet studied in detail the incidence of cases complicated by some other renal disease.

The pathogenesis of the disease is not yet fully understood. The mean thickness of normal glomerular basement membrane in infants and young children is $110 \mathrm{~nm}-$ much less than that of older children and adults $(270 \mathrm{~nm}) .{ }^{11}$ The thickness gradually increases in early childhood but changes little with increasing age in adults. ${ }^{11}$ The widespread thinning was thought to be the result of incomplete maturation of glom- erular basement membrane. ${ }^{4}$ Further investigation is required to understand this problem more completely.

The authors are grateful to Dr J Churg for reviewing the manuscript.

\section{References}

1 Churg J, Sobin LH. Renal disease. Classification and atlas of glomerular diseases. Tokyo: Igaku-shoin, 1982.

2 Piel CF, Biava CG, Goodman JR. Glomerular basement membrane attenuation in familial nephritis and "benign" hematuria. J Pediatr 1982;101:358-65.

3 Tina L, Jenis E, Jose P, Medani C, Papadopoulou Z, Calcagno P. The glomerular basement membrane in benign familial hematuria. Clin Nephrol 1982;17:1-4.

4 Yoshikawa N, Hashimoto H, Katayama Y, Yamada Y, Matsuo $\mathrm{T}$. The thin glomerular basement membrane in children with hematuria. J Pathol 1984;142:253-7.

5 Shigematsu H, Kobayashi Y, Tateno S, Hiki Y, Kuwao S. Ultrastructural glomerular loop abnormalities in IgA nephritis. Nephron 1982;30:1-7.

6 Rogers PW, Kurtzman NA, Bunn SM Jr, White MG. Familial benign essential hematuria. Arch Intern Med 1973;131:257-62.

7 Dische FE, Weston MJ, Parsons V. Abnormally thin glomerular basement membranes associated with hematuria, proteinuria or renal failure in adults. Am J Nephrol 1985;5:103-9.

8 Osawa G, Kimmelstiel P, Seiling V. Thickness of glomerular basement membrane. Am J Clin Pathol 1966;45:7-20.

9 Trachtman H, Weiss RA, Bennett B, Greifer I. Isolated hematuria in children: Indications for a renal biopsy. Kidney Int 1984;25:94-9.

10 Yum M, Bergstein JM. Basement membrane nephropathy: a new classification for Alport's syndrome and asymptomatic hematuria based on ultrastructural findings. Hum Pathol 1983;14:996-1003.

11 Bloom PM, Hartmann JF, Vernier RL. An electron microscopic evaluation of the width of normal glomerular basement membrane in man at various ages. Anat Rec 1959;133:251.

Requests for reprints to: Dr S Abe, Department of Internal Medicine, Keio University School of Medicine, 35 Shinanomachi, Shinjuku-ku, Tokyo, 160, Japan. 